Acta vet. scand. $1976,17,458-464$.

From the National Veterinary Institute, Oslo, Norway.

\title{
AN IMPROVED BACTERIOLOGICAL METHOD FOR THE DETECTION OF SULFONAMIDE RESIDUES IN FOOD
}

\author{
By \\ Roar Gudding
}

\begin{abstract}
GUDDING, ROAR: An improved bacteriological method for the detection of sulfonamide residues in food. Acta vet. scand. 1976, 17, 458-464. - The addition of trimethoprim to Mueller-Hinton medium was found to improve the sensitivity of test bacteria towards sulfonamides by $20-50$ times. Depending on the test bacteria used, the optimal concentrations of trimethoprim added to the medium are $1 \mu \mathrm{g}$ per ml (Micrococcus luteus), $0.25 \mu \mathrm{g}$ per $\mathrm{ml}$ (Bacillus stearothermophilus var. calidolactis) and $0.1 \mu \mathrm{g}$ per $\mathrm{ml}$ (Bacillus megaterium). Using Micrococcus luteus or Bacillus megaterium a concentration of $0.25 \mu \mathrm{g}$ sulfanilamide per ml may be detected, and $0.1 \mu \mathrm{g}$ per ml may be detected when Bacillus stearothermophilus var. calidolactis is used.

detection of sulfonamides; trimethoprim; Micrococcus luteus; Bacillus megaterium; Bacillus stearothermophilus var. calidolactis.
\end{abstract}

The detection of small concentrations of sulfonamides in milk or meat by bacteriological methods requires a sensitive test bacteria and a medium with a low content of sulfonamide antagonists. Micrococcus luteus (Sarcina lutea), Bacillus megaterium and Bacillus stearothermophilus var. calidolactis have usually been used as test bacteria. A medium described by Mueller \& Hinton (1941) has been used for the detection of small concentrations of sulfonamides in milk (Read et al. 1971, Gudding \& Hellesnes 1973) and in meat (Yndestad \& Ørbeck Sфrheim 1975).

The content of sulfonamide antagonists in Mueller-Hinton medium is fairly low, and using B. megaterium, a concentration of $7.5 \mu \mathrm{g}$ sulfanilamide per $\mathrm{ml}$ may be detected (Gudding 1974 a). Using a medium containing Vitamin-Free Casamino Acids as the only nutrient source, the growth of $\mathrm{B}$. megaterium was in- 
hibited by $2.5 \mu \mathrm{g}$ sulfanilamide per ml (Gudding $1974 \mathrm{~b}$ ). The sensitivity of the bacteriological methods is still too low, however, for routine examinations in milk and meat control.

Trimethoprim is a chemotherapeutic agent with an antibacterial effect due to the inhibition of bacterial dihydrofolate reductases which are essential for the synthesis of purines and other biological substances with methyl or formyl groups (Bushby \& Hitchings 1968). Sulfonamides and trimethoprim inhibit the enzymes in two sequential steps in the biosynthesis of tetrahydrofolate (Hitchings 1969), and they have a synergistic effect which has been used for therapeutical purposes for some years.

The aim of the present work was to improve the bacteriological methods for the detection of sulfonamide residues, using the synergistic effect of trimethoprim and sulfonamides. The aim was to incorporate trimethoprim in the test medium at concentrations which by themselves only give slight growth inhibition of the different test organisms.

\section{MATERIAL AND METHODS}

Mueller-Hinton medium * was used as test medium throughout the investigation. A medium consisting of Vitamin-Free Casamino Acids ${ }^{\star} 1.0 \%$ and agar $1.5 \%$ was also used in part of the work. The test agar preparation, sample application and incubation using Micrococcus luteus ATCC 9341** and Bacillus megaterium ATCC 9885 were performed as described by Gudding \& Hellesnes (1973). The concentration of test bacteria in the agar was, however, increased to $1.5 \cdot 10^{6}$ per $\mathrm{ml}$ (M.luteus) and $0.2 \cdot 10^{6}$ per ml (B. megaterium), respectively. A commercially available spore suspension of Bacillus stearothermophilus var. calidolactis $^{\star \star *}$ was used in the experimental work. The test agar with B. stearothermophilus var. calidolactis was prepared as described by the manufacturer with the exception that Mueller-Hinton medium containing brom cresol purple $(0.016 \%)$ was used as test medium. The incubation temperature for this bacteria was $65^{\circ} \mathrm{C}$.

Trimethoprim, from a stock solution containing $10.0 \mathrm{mg}$ per

* Difco Laboratories Inc., Michigan, USA.

* * ATCC: American Type Culture Collection, Rockville, Maryland, USA.

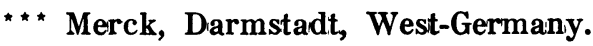


$100 \mathrm{ml}$, was mixed with the agar to various concentrations before pouring the medium into Petri dishes. Sulfanilamide, sulfamethazine and sulfaphenazole were diluted in water to suitable concentrations. Aliquots of these dilutions were applied in circular wells of $10 \mathrm{~mm}$ diameter in the agar layer, which was $2 \mathrm{~mm}$ thick. Inhibition of bacterial growth was monitored by measuring the diameters of the growth inhibition zones around the wells.

\section{RESULTS}

The lowest concentrations of sulfanilamide detected using M. luteus grown in Mueller-Hinton medium with and without the addition of $1.0 \mu \mathrm{g}$ trimethoprim per ml were 0.25 and $10.0 \mu \mathrm{g}$ per ml, respectively (Fig. 1). By increasing the concentration of trimethoprim to $1.5 \mu \mathrm{g}$ per $\mathrm{ml}$ and the inoculate of test bacteria by 1 log., a concentration of $0.1 \mu \mathrm{g}$ sulfanilamide per $\mathrm{ml}$ gave significant inhibition zones.

B. stearothermophilus var. calidolactis was inhibited by 5.0 $\mu \mathrm{g}$ sulfanilamide per $\mathrm{ml}$ when grown in Mueller-Hinton medium. Using Mueller-Hinton medium with trimethoprim added to a concentration of $0.25 \mu \mathrm{g}$ per $\mathrm{ml}$, even $0.1 \mu \mathrm{g}$ sulfanilamide per $\mathrm{ml}$ could be detected (Fig. 2). Concentrations of trimethoprim up

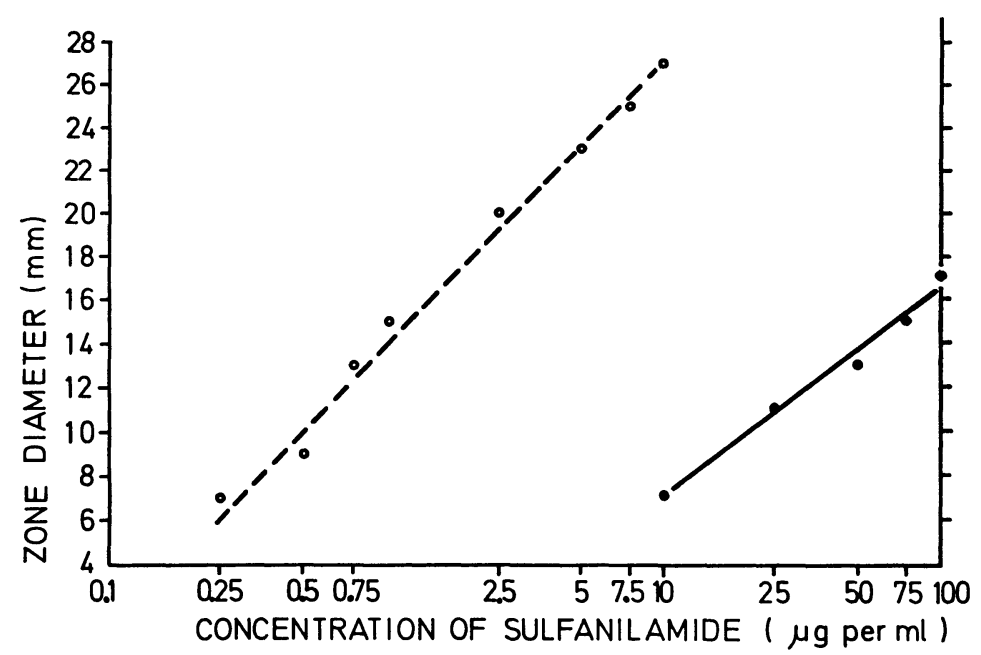

Figure 1. Diameters of inhibition zones as a function of sulfanilamide concentration in Mueller-Hinton medium ( $\bullet-\bullet)$ and Mueller-Hinton medium containing $1.0 \mu \mathrm{g}$ trimethoprim per $\mathrm{ml}$ $(0-\ldots--0)$ using Micrococcus luteus as test bacteria. 


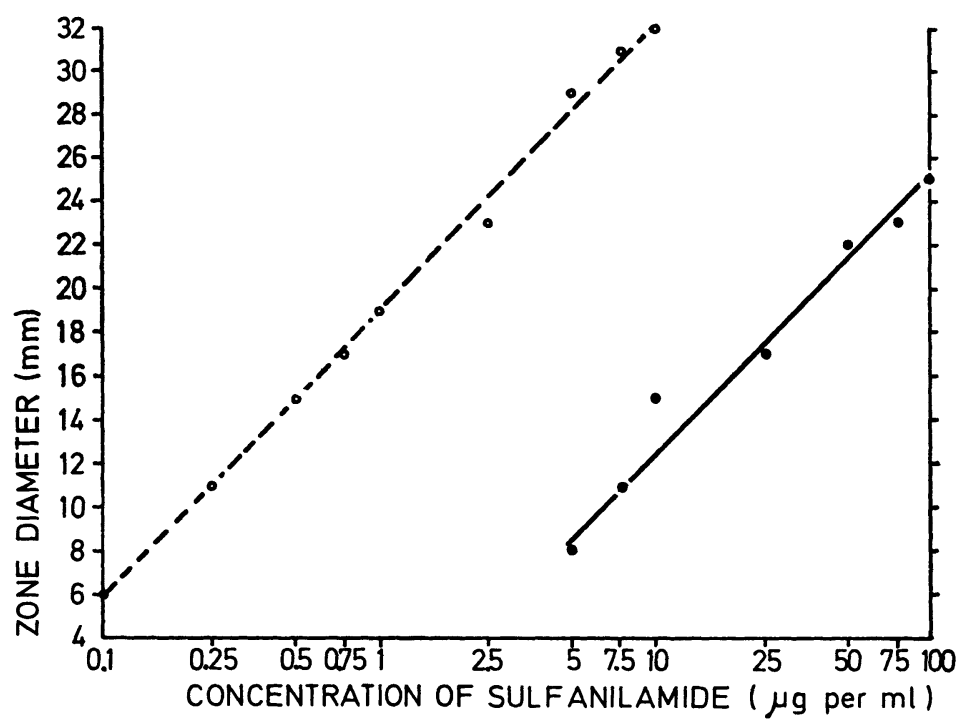

Fig u re 2. Diameters of inhibition zones as a function of sulfanilamide concentration in Mueller-Hinton medium ( $\bullet-\bullet$ ) and Mueller-Hinton medium containing $0.25 \mu \mathrm{g}$ trimethoprim per $\mathrm{ml}$ (o-...-o) using Bacillus stearothermophilus var. calidolactis as test bacteria.

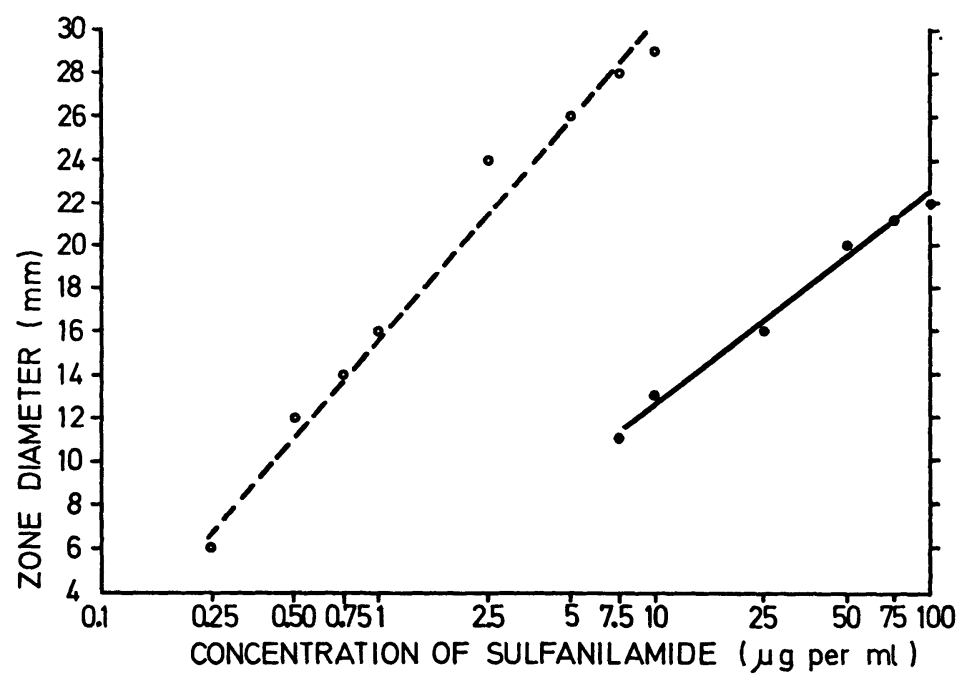

Figure 3. Diameters of inhibition zones as a function of sulfanilamide concentration in Mueller-Hinton medium ( $\bullet-\bullet)$ ) and Mueller-Hinton medium containing $0.1 \mu \mathrm{g}$ trimethoprim per ml (o-....- o) using Bacillus megaterium as test bacteria. 
to $0.4 \mu \mathrm{g}$ per $\mathrm{ml}$ could be added to Mueller-Hinton medium without inhibiting the growth of $\mathrm{B}$. stearothermophilus var. calidolactis to any great extent. The addition of trimethoprim gave, however, a prolongation of the incubation time from about $4 \mathrm{hrs}$. to 6-7 hrs. with the highest amount of trimethoprim.

When B. megaterium was used as test bacteria the lowest detectable concentrations of sulfanilamide with and without 0.1 $\mu \mathrm{g}$ trimethoprim per $\mathrm{ml}$ were $0.25 \mu \mathrm{g}$ and $7.5 \mu \mathrm{g}$ per $\mathrm{ml}$, respectively (Fig. 3). B. megaterium had also to be incubated 2 to 3 hrs. longer for sufficient growth when grown in a medium containing trimethoprim.

The lowest detectable concentrations of sulfanilamide, sulfamethazine and sulfaphenazole with the three test bacteria grown in Mueller-Hinton medium can be seen in Table 1. The increase in sensitivity for all the sulfonamides was generally of the order of $20-50$ times.

T able 1. Lowest detectable concentrations of some sulfonamides using Mueller-Hinton medium with and without the addition of trimethroprim.

\begin{tabular}{|c|c|c|c|c|}
\hline Test bacteria & $\begin{array}{l}\text { Concentration } \\
\text { f trimethoprim } \\
\mu \mathrm{s} \text { per ml }\end{array}$ & $\begin{array}{l}\text { Sulfanilamide } \\
\mu \mathrm{g} \text { per ml }\end{array}$ & $\begin{array}{c}\text { Sulfamethazine } \\
\mu \mathrm{g} \text { per ml }\end{array}$ & $\begin{array}{l}\text { Sulfaphenazole } \\
\mu \text { \& per ml }\end{array}$ \\
\hline Micrococcus luteus & 0 & 10.0 & 10.0 & 1.0 \\
\hline$川$ & 1.0 & 0.25 & 0.25 & 0.025 \\
\hline $\begin{array}{l}\text { Bacillus stearothermo- } \\
\text { philus var. calidolactis }\end{array}$ & is & 5.0 & 2.5 & 0.5 \\
\hline " & 0.25 & 0.1 & 0.1 & 0.01 \\
\hline Bacillus megaterium & 0 & 7.5 & 7.5 & 1.0 \\
\hline$\eta$ & 0.1 & 0.25 & 0.25 & 0.025 \\
\hline
\end{tabular}

The medium with Vitamin-Free Casamino Acids gave no growth of M. luteus and B. stearothermophilus var. calidolactis. When $0.05 \mu \mathrm{g}$ trimethoprim per $\mathrm{ml}$ was added to the medium, the growth of B. megaterium was only slightly inhibited and a concentration of $0.75 \mu \mathrm{g}$ sulfanilamide per ml could be detected.

When trimethoprim was incorporated in the media, the growth inhibition was complete even at low sulfonamide concentrations. However, in the periphery of the zones there was a weaker inhibition of growth, as can be seen in zones produced by sulfonamides only. 
The addition of p-aminobenzoic acid (p-ABA) to the sample or to the medium was found to inhibit the bacteriostatic effect of the sulfonamides. Consequently, this procedure can be used for identification of sulfonamides also when trimethoprim is added to the medium.

The sensitivities of the test bacteria towards penicillin, streptomycin and tetracyclines do not seem to be influenced by the addition of trimethoprim to the Mueller-Hinton medium.

\section{DISCUSSION}

By using the synergistic effect of sulfomamides and trimethoprim, the sensitivity of the agar diffusion test may be increased from 20 to 50 times compared with the bacteriological methods which are used at the present time. In addition, the inhibition zones are more distinct due to more complete bacterial growth inhibition. This is in accordance with the statement that a combination of trimethoprim and sulfonamides has a synergistic bactericidal effect (Bushby 1969).

One consequence of the introduction of an antibacterial component in the medium is, however, a greater possibility for error and consequently incorrect results. Thus, too high concentrations of trimethoprim, or even too small inoculates, may give slight or no growth of the test bacteria. The procedure of medium preparation should therefore be highly standardized in order to avoid erroneous results.

In our laboratory, which is concerned with milk analysis, M. luteus is used as test organism. A concentration of $0.8 \mu \mathrm{g}$ trimethoprim per $\mathrm{ml}$ is added to Mueller-Hinton medium in routine work, and residues of sulfonamides in bulk milk have already been detected by the improved method.

In meat control, the need for a sensitive bacteriological method for the detection of sulfonamides is probably greater than in milk control. Animals slaughtered in emergency are sometimes treated systemically with sulfa drugs, and a consequence of inadequate bacteriological methods has been the application of labourious chemical methods, or approval of meat with sulfonamide residues.

In practical routine work, M. luteus or B. stearothermophilus var. calidolactis have been found to be the most suitable test bacteria due to their high sensitivity towards penicillin. 
The prolonged incubation period may be an disadvantage when B. stearothermophilus var. calidolactis is used, as the plates or Petri dishes cannot be read within the working time of an ordinary day. M. luteus should always be incubated overnight, and a period of $18 \mathrm{hrs}$. is sufficient incubation time when $1.0 \mu \mathrm{g}$ trimethoprim per $\mathrm{ml}$ is added to the medium.

\section{REFERENCES}

Bushby, S. R. M.: Combined antibacterial action in vitro of trimethoprim and sulphonamides. Postgrad. med. J. 1969, 45, 10-18.

Bushby, S. R. M. \& G. H. Hitchings: Trimethoprim, a sulphonamide potentiator. Brit. J. Pharmacol. 1968, 33, 72-90.

Gudding, R.: The suitability of some media and peptones for sulfonamide testing. Acta vet. scand. 1974 a, 15, 366-380.

Gudding, R.: Et enkelt medium til påvisning av restkonsentrasjoner av sulfonamider. (A simple medium for the detection of sulfonamides). 12th Nord. Vet. Congress, Proc. 1974 b, 282.

Gudding, R. \& I. Hellesnes: Påvisning av sulfonamider i melk. (Detection of sulfonamides in milk). Nord. Vet.-Med. 1973, 25, 248255.

Hitchings, G. H.: Species differences among dihydrofolate reductases as a basis for chemotherapy. Postgrad. med. J. 1969, 45, 7-10.

Mueller, J. H. \& J. Hinton: A protein-free medium for primary isolation of the gonococcus and meningococcus. Proc. Soc. exp. Biol. (N.Y.) $1941,48,330-337$.

Read, R. B., jr., J. G. Bradshaw, A. A. Swartzentruber \& A. R. Brazis: Detection of sulfa drugs and antibiotics in milk. Appl. Microbiol. 1971, 21, 806-808.

Yndestad, M. \& A. Ørbeck Sфrheim: Forekomst av veksthemmende stoffer i normale slaktedyr i Norge i 1973/1974. (Occurrence of growth inhibiting substances in healthy slaughter animals in Norway in 1973/1974). Norsk Vet.-T. 1975, 87, 477-479.

\section{SAMMENDRAG \\ En forbedret bakteriologisk metode til påvisning av sulfonamider $i$ næringsmidler.}

Tilsetning av trimethoprim til Mueller-Hinton medium $\phi$ kte f $\varnothing$ lsomheten av ulike testbakterier overfor sulfonamider med fra 20 til 50 ganger. Den optimale konsentrasjonen av trimethoprim i mediet var $1 \mu \mathrm{g}$ per $\mathrm{ml}$ (Micrococcus luteus), 0,25 $\mu \mathrm{g}$ per $\mathrm{ml}$ (Bacillus stearothermophilus var. calidolactis) og $0,1 \mu \mathrm{g}$ per $\mathrm{ml}$ (Bacillus megaterium). Ved bruk av Micrococcus luteus og Bacillus megaterium kunne en påvise $0,25 \mu \mathrm{g}$ sulfanilamid per ml, mens $0,1 \mu \mathrm{g}$ per ml kunne påvises når en brukte Bacillus stearothermophilus var. calidolactis som testbakterie.

$$
\text { (Received October 4, 1976). }
$$

Reprints may be requested from: Roar Gudding, the National Veterinary Institute, Postbox 8156, Oslo Dep., Oslo 1, Norway. 